\title{
Soil compaction on skid trails after selective logging in moist evergreen forest of Ghana
}

\author{
Afrifa Baffour Alexander \\ Faculty of Forest Resources Technology, KNUST, Sunyani, Ghana \\ ABSTRACT
}

\begin{abstract}
Soil compaction has been considered as a principal form of damage associated with logging, restricting root growth and reducing natural regeneration. There is no information on the changes in compaction and extent of soil recovery over time. This study evaluates the effects of logging on soil compaction in moist evergreen forest of Ghana. The extent of soil compaction on skid trails was measured at six locations: two plots on the edges, two on the center and two on the unlogged area as a control and replicated seven times on a forty year and one year old skid trails. Penetration resistance was measured to determine the extent of soil compaction using the soil penetrometer. In the forty year old skid trail, penetration resistance was significantly higher at the edge and center as compared to the unlogged area. In the one year old skid trail, penetration was only significantly higher at the edge than the unlogged. Comparing the two skid trails, recovery rate of surface soil compaction showed no significant difference over the period, illustrating the persistent effect of heavy machinery compaction on surface soil structure.
\end{abstract}

Keywords: Compaction, soil recovery, natural regeneration, skid trail, Penetration resistance.

\section{INTRODUCTION}

Logging is perceived to be one of the major causes of damage to forest vegetation. However, low intensity selective logging which is widely practiced in the tropical rainforests has been observed to be one of the least destructive land use systems in the tropics (Hendrison, 1990). Logging operations can cause significant and widespread soil disturbance which adversely affects soil physical properties and nutrient levels to extents that severely diminishes growth of subsequent tree rotations and significantly increase runoff and sediment.

In Ghana, logging operations are estimated to affect between 10-25 percent of the total area of the forest through logging roads and tracks (Hawthorne and Abu-Juam, 1993). In many areas currently exploited for timber in the tropics, slopes are steep and logs are heavy such that only heavy and powerful bulldozers can be used to extract the logs, but these machines may have serious effects on forest as well as on other ecosystems. The extraction methods that are being used, if not controlled may result in soil compaction, decreased pore space, decreased water infiltration rates, thereby increasing runoff and making it difficult for natural regeneration to occur (Prayudi, 1996). There are also negative effects on seedling establishment and growth due to skidding which are often attributed to changes associated with soil compaction, including reduced infiltration rates and increased resistance to root penetration (Woodward, 1995). Dykstra and Heinrich, (1996) also listed several common types of damages caused to forest ecosystems if proper attention is not given during log extraction.

There is no information on the changes in compaction over time and the extent of soil recovery following soil compaction. Therefore, this study seeks to determine the extent of soil compaction recovery over a 40-year period. The objectives of the study are to determine the extent of soil compaction on different sections of the skid trail in a 40-year old abandoned skid trail and a one-year old skid trail.

\section{MATERIALS AND METHODS}

Study area: The study was conducted at Boin River Forest Reserve situated in the high forest zone and described as the moist evergreen type (Hall and Swaine, 1981), with annual rainfall around $1700 \mathrm{~mm}$. The soils are the oxysol-ochrosol intergrade, clearly poorer in nutrients (Hall and Swaine, 1981). Boin River Forest Reserve is being logged selectively by Samartex Timber and Plywood Company Limited (SAX).

Plots of $0.5 \mathrm{~m} \times 2 \mathrm{~m}$ were laid in compartment 110 of the forest reserve. The plots were laid on both the forty year old abandoned primary skid trail and a one year old primary skid trail in the same compartment. Two plots were laid on both edges of the skid trail, and another two plots laid at the center of the skid trail. Control plots were established at two meters from the skid trail on both sides of the skid trail. In all, six plots were established and this procedure was replicated for seven times on both the 40-year old abandoned skid trail and a one-year old skid trail. The readings were 
taken at all the four corners and the middle of the plots that is, five locations at a depth of about $10 \mathrm{~cm}$ as the constant depth for soil penetrometer measurement throughout the experiment. Soil compaction was measured using the soil penetrometer. The data was analyzed using the Analysis of Variance and the result was presented on tables and graphs.

\section{RESULTS}

On the 40-year old skid trial, the edge section of the skid trail recorded the highest mean value of 167.6, representing $36.84 \%$ (Fig.1), followed by the center which recorded 148.4 representing $32.62 \%$. The unlogged or control section of the skid trail recorded the least mean value of 139 representing $30.54 \%$. At a Least Significant Difference (LSD) of 9.12, there was a significant amount of soil compaction measured as penetration resistance in all the two parameters compared to the unlogged at 0.05 significance level.

On the one-year old skid trail, the edge section of the skid trail recorded the highest mean value of 152.4 representing $36.91 \%$, followed by the center of the skid trail which recorded 140.1 representing $33.93 \%$. The unlogged or control section of the skid trail recorded the least mean value of 120.4 representing $29.16 \%$. At $0.05 \%$ of significant level, the penetration resistance between the edge and the unlogged was 32 , showing a high penetration resistance. The penetration resistance between the center and the unlogged is not significant (Fig. 2). From the results the difference in rate of recovery between the 40-year old abandoned skid trail and the one year old skid trail is not significant (Fig.3).

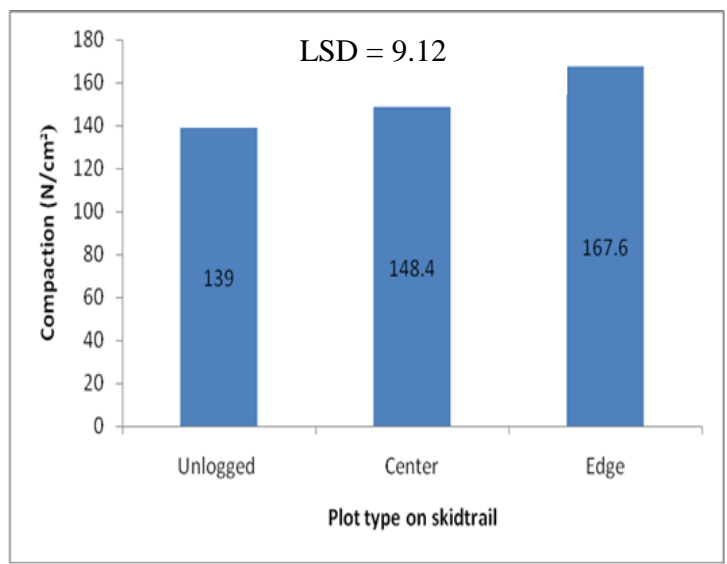

Fig.1: The mean plot values for different sections on a 40-year old skid trail

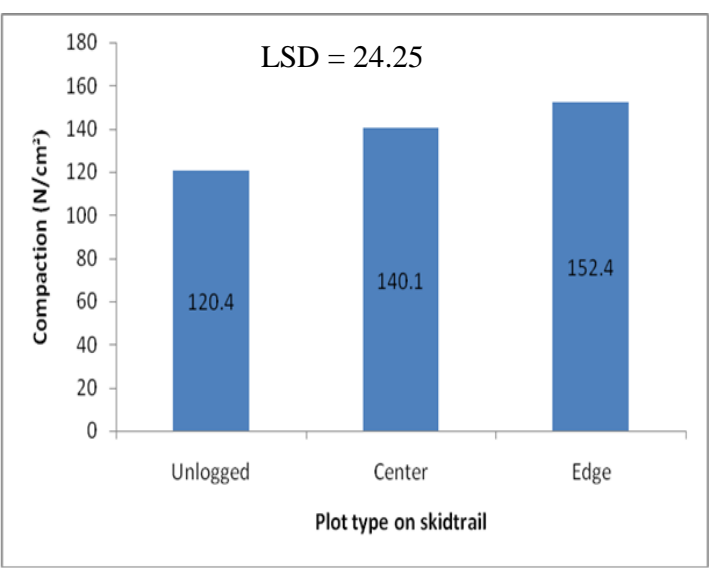

Fig.2: The mean plot values for different sections on a fresh skid trail (1 year old)

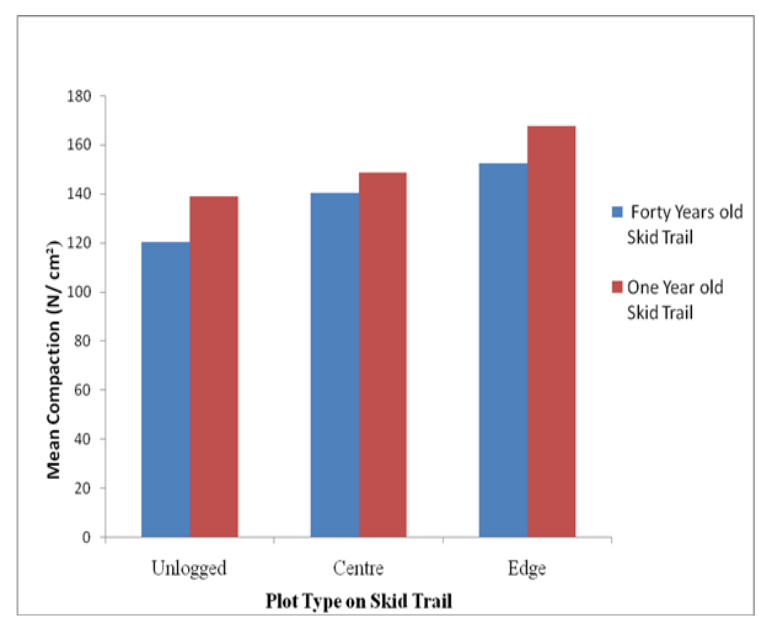

Fig.3: Mean plots values between the $\mathbf{4 0}$ and 1-year old skid trails.

\section{DISCUSSION}

The forty year old skid trail: The significantly higher penetration resistance on the 40-year old skid trial is an indication of higher soil strength and a reliable indicator of terrain trafficability (Hendrison, 1990). Once the topsoil, litter and vegetation are removed and the soil is compacted during skid trail construction, soil pore volumes and water infiltration rates decrease (Muhammad, 1996). This could have adverse effect on soil water retention, aeration and root penetration and for that matter tree growth. Woodward (1996) reported that, the use of heavy machinery in forests leads tosoil disturbance and degradation and the effects will, like canopy opening, not be uniform throughout the forest but will be greatest on those areas such as roads, log landing bays, tracks and skid trails. 
The one year old skid trail: Significantly higher penetration on edge as compared to the control could be attributed to the number of passes of the skidder with and without a log and machines that were being used to skid the logs. Tampokong (1996) stated that, the number of passes of crawler tractors on the same skid trail further influences the degree of compaction which in turn affects water infiltration rates. Furthermore, the type of machine that was used to skid the logs in the one year old skid trail was the D6 brand skidders. These types of machines are smaller and lighter than the D8 brand skidders that were being used to skid the logs in the 40-year old skid trail.

Comparing the center and the unlogged area of the one year old skid trail, the penetration resistance was almost the same and the reason could be that the center only receives the impact from the skidder when the logs are being skid on it.

The forty and one year old skid trails: The significantly low soil compaction recovery between the two skid trials could be due to the nature of the soil type and the management practices that was being used to skid the logs. In the 40-year old skid trail, the management practice that was being deployed is the conventional method of harvesting and these practices do not follow any pre-harvesting planning. Malmer and Grip (1990) working in Sabah found that bulk density and penetration resistance of soilon six-year-old tractor tracks was nearly $60 \%$ higher than the soil of the undisturbed forest. They also found out that the impact of tractors was significantly greater on clay soils than on sandy soils, and tractors were found to have compacted both soils more severely than log extraction without the use of such heavy machinery.

Skid trails were estimated to take an average of 22 years to recover natural bulk density, porosity and resistance to penetration and 52 years to recover saturated hydraulic conductivity, while secondary forest road was estimated to take an average of 14 and 28 years to recover these same properties (Kamaruzaman, 1996). The results of this study clearly demonstrate that the type of machines that were used to skid logs on skid trails influences the recovery of soil compaction as a measure of penetration resistance even 40 years after logging in the forest reserve, the amount of recovery of soil compaction is not significant.

\section{CONCLUSION}

In conclusion, 40 years after logging has not produced a significant difference in soil compaction on the various plot types as compared to the unlogged (control). Recovery from soil compaction has been low due to the type of machines and the management plan that was used to skid the logs in the reserve. Furthermore, the rate of recovery of soil compaction between the 40-year old abandoned skid trail and the one year old skid trail is significantly low even after forty years. Consequently, soil damage in the tropical rainforest is extremely high during timber harvesting operations using heavy machines.

\section{ACKNOWLEDGEMENT}

I am thankful to the management and the entire staff of the Samartex Timber and Plywood Company Limited (SAX) for their contributions and support in the area of advice, criticisms and suggestions.

\section{REFERENCES}

Dykstra, D.P. \& Heinrich, R. (1996). FAO Model Code of Forest Harvesting Practice. Food and Agriculture Organization of the United Nations, Rome, Italy, $422 \mathrm{pp}$.

Hall, J. B. \& Swaine, M.D. (1981). Distribution and ecology of vascular plants in tropical rainforest vegetation in Ghana. W. Junk. The Hague. Pp 20-23.

Hawthorne, W.D. and Abu-Juam, M. (1993). Gap-phase dynamics and tropical tree species richness in tropical forest. Journal on Ecology. Vol.23: pp 45.

Hendrison, J.B. (1990). Damage-controlled logging in managed tropical rain forest in Suriname. Agricultural University Uageningn. The Netherlands. 204pp.

Kamaruzaman, J. (1996). Estimation of rate of recovery of disturbed soils from ground-based logging in Peninsular Malaysia. McGraw Hill Book Co. Pp 80-83.

Malmer, A. and Grip, H, (1990). Soil disturbance and loss of infiltrability caused by mechanised and manual extraction of tropical rainforest in Sabah, Malaysia. Pp 41-43.

Muhammad Farid, A.R. (1996). Water infiltration rates on a skidtrail and adjacent residual forest 20 years after logging in East Kalimantan, Indonesia. In: Research Methods for Reduced-Impact Logging: Workshop Results. F.E. Putz, Elias, D. Dykstra, and R. Heinrich, editors. CIFOR Special Publication. Pp 100-112.

Prayudi, H. (1996). Soil loss in relation to skid trail slope after selective logging. Oxford: Blackwell Scientific Publications pp 77-78.

Tampokong, M.D. (1996). Effect of wood extraction by crawler tractors on infiltration rates on a skidtrail 20 years after logging in East Kalimantan, Indonesia. In: Research Methods for Reduced-Impact Logging: Workshop Results. F.E. Putz, Elias, D. Dykstra, and R. Heinrich, editors. CIFOR Special Publication. Pp 143-152.

Woodward, C.L. (1995). Soil compaction and top soil removal during mechanized clearing of tropical forest: effects on soil properties and seedling growth. Pp 45-48

Woodward, C.L. (1996).Soil compaction and topsoil removal effects on soil properties and seedling growth in Amazonian Ecuador. Journal of Tropical Forest Science, Vol. 14. Pp 30-31. 